\title{
Cardiac arrhythmias in highlanders with a diagnosis of chronic cor pulmonale
}

\author{
Arritmias cardíacas en habitantes de gran altura con diagnóstico de corazón pulmonar \\ crónico
}

\author{
Ricardo Sosa-Villarreal1* and José M. Arce-Carreón ${ }^{2}$ \\ ${ }^{1}$ Department of Cardiology; ${ }^{2}$ Department of Electrophysiology, Instituto Nacional de Tórax, La Paz, Bolivia
}

\begin{abstract}
Background: Chronic cor pulmonale $(C P C)$, with increased presentation in high-altitude inhabitants. Objectives: The objectives of the study were to investigate the frequency of cardiac arrhythmias and risk factors for its development. Methods: $A$ descriptive, cross-sectional study, the inpatient registry of the Department of Cardiology of the National Institute of Thorax, La Paz-Bolivia, from January 2017 to June 2018 was reviewed, all were incorporated with the diagnosis of CPC, defined by clinical criteria, electrocardiographic and echocardiographic, 162 patients who met the criteria were taken, the Student's $t$-test and ANOVA were used for the analysis. Results: Arrhythmias: atrial fibrillation (AF) 125 (75\%), atrial flutter (AA) 17 (10.5\%), atrial tachycardia (AT) 17 (10.5\%), and extrasystoles $3(1.9 \%)$. Univariate analysis of factors related to the development of arrhythmias: erythrocytosis: $F A, R R: 1.33$, other arrhythmias $R R: 1.67, p=0.0001$, pulmonary arterial hypertension: $F A, R R$ : 3.10, other arrhythmias RR: 3.21, $p=0.0001$, right atrial dilation $(A D)$ : $F A, R R: 1.92$, other arrhythmias $R R: 2.13, p=0.0001$, obesity: FA, RR: 3.47, $p=0.001$, other arrhythmias RR: 3.70, $p=0.001$, systemic arterial hypertension: FA: RR: 3.10, $p=0.001$, and other arrhythmias RR: 3.21, $p=0.001$. Multivariate analysis: erythrocytosis (RR: 2.2), AD dilation (RR: 1.2), $p=0.0001$. Conclusions: $A F$ was found more frequently in patients with $C P C$, the risk factors with the greatest statistical significance for presentation were erythrocytosis and $A D$ dilation.
\end{abstract}

Key words: Atrial fibrillation. Pulmonary arterial hypertension. Erythrocytosis.

\section{Resumen}

Antecedentes: El corazón pulmonar crónico (CPC) muestra un incremento en habitantes que viven en grandes altitudes. Objetivo: Investigar la frecuencia de arritmias cardíacas y factores de riesgo para su desarrollo. Métodos: Estudio descriptivo y transversal; se revisó el registro de pacientes internados del Departamento de Cardiología del Instituto Nacional de Tórax, La Paz, Bolivia, entre enero de 2017 y junio de 2018; se incorporó a todos los individuos con diagnóstico de CPC, definido por criterios clínicos, electrocardiográficos y ecocardiográficos; se incluyó a 162 pacientes que cumplieron los criterios en el análisis; se utilizaron la t de Student y ANOVA. Resultados: Arritmias: fibrilación auricular (FA), 125 (75\%); aleteo auricular (AA), 17 (10.5\%); taquicardia auricular (TA), 17 (10.5\%); extrasístoles, 3 (1.9\%). Según el análisis univariado, los

\section{Correspondence:}

${ }^{*}$ Ricardo Sosa Villarreal

E-mail: costarestera@ hotmail.com
Date of reception: 08-11-2019

Date of acceptance: 22-03-2020

DOI: 10.24875/ACME.M20000150
Available online: 02-03-2021 Arch Cardiol Mex (Eng). 2020;90(4):380-384 www.archivoscardiologia.com 2604-7063 / C 2020 Instituto Nacional de Cardiología Ignacio Chávez. Published by Permanyer. This is an open access article under the CC BY-NC-ND license (http://creativecommons.org/licenses/by-nc-nd/4.0/). 
factores relacionados con el desarrollo de arritmias fueron: eritrocitosis: $F A, R R$ : 1.33, otras arritmias (RR: 1.67), $p=0.0001$; hipertensión arterial pulmonar: $F A, R R$ : 3.10, otras arritmias (RR: 3.21), $p=0.0001$; dilatación de aurícula derecha $(A D)$ : $F A$, $R R$ : 1.92, otras arritmias (RR: 2.13), $p=0.0001$; obesidad: $F A, R R: 3.47, p=0.001$, otras arritmias (RR: 3.70), $p=0.001$; hipertensión arterial sistémica: $F A, R R: 3.10, p=0.001$, otras arritmias (RR: 3.21$), p=0.001$. Según el análisis multivariado: eritrocitosis (RR: 2.2), dilatación de $A D$ (RR: 1.2), $p=0.0001$. Conclusiones: Se encontró FA con mayor frecuencia en los pacientes con CPC; los factores de riesgo con mayor significancia estadística para su presentación fueron la eritrocitosis y la dilatación de la $A D$.

Palabras clave: Fibrilación auricular. Hipertensión arterial pulmonar. Eritrocitosis.

\section{Introduction}

The cities of La Paz and El Alto are at 3,577 and 4,050 $\mathrm{MASL}^{1}$, respectively, and, together, they have a population of 2,904,996 inhabitants, out of whom half is spread at different ecological levels of the La Paz department; barometric pressure at this altitude is 490 $\mathrm{mmHg}$ and $\mathrm{FiO}_{2}, 0.21$ (21\%), with very special climatic variations and cold and dry temperatures.

As a chronic acclimatization mechanism, natives to this height have higher pulmonary pressure values than those who live at sea level, with normal pulmonary pressure for the altitude ${ }^{1}$.

Chronic cor pulmonale (CCP) is a right ventricular (RV) structural alteration (hypertrophy or dilatation) and functional impairment resulting from pulmonary pressures elevation in relation to diseases of the lung parenchyma and its vascularization, of the upper respiratory tract, or chest wall. RV dysfunction due to the left-sided heart disease or congenital heart disease is not regarded as $\mathrm{CCP}^{2}$.

In the field of work, this population is found in, CCP is a common heart condition ${ }^{3,4}$, as an effect of alterations that occur with hypoxemia or pulmonary vascular-arterial obstruction. It has a solid connection with chronic obstructive pulmonary disease, pulmonary tuberculosis chronic sequelae, and pulmonary thromboembolic disease.

CCP incidence and prevalence are variable due to the diversity of entities that trigger it and, consequently, its epidemiology is linked to the causes that originate it.

\section{Material and Methods}

This study is of descriptive and cross-sectional nature and was performed from January 2017 to June 2018. Its purposes were to determine which cardiac arrhythmias are the most common in CCP diagnosed patients admitted to the Cardiology Department of the National Thorax Institute of La Paz, Bolivia, and to find out the predisposing risk factors for the development of cardiac arrhythmias. For data collection, the medical records of patients admitted to this hospital were reviewed; the inclusion criteria asked for patients with CCP established diagnosis through clinical (increased second heart sound, presence of tricuspid regurgitation murmur or pulmonary insufficiency, and systemic venous congestion), electrocardiographic (RV Sokolow-Lyon > $11 \mathrm{~mm}$, and Lewis indices <-14 mm), and echocardiographic criteria, with RV dimensions and systolic pulmonary artery pressure (sPAP) determination being obtained by this same method (RV free wall thickness $>5 \mathrm{~mm}$ increase, RV basal segment dilatation $>42 \mathrm{~mm}$, RV length $>86 \mathrm{~mm}$, tricuspid regurgitation, sPAP > $35 \mathrm{mmHg}$, and right atrium (RA) dilatation $>18 \mathrm{~cm}^{2}$ ), with permanent residence in the cities of $\mathrm{La}$ Paz and El Alto, with patients with diseases other than pulmonary hypertension (hypertensive heart disease, ischemic heart disease, and rheumatic heart disease) being excluded.

The risk factors that were found were high altitude pathological erythrocytosis (hemoglobin $>17 \mathrm{~g} / \mathrm{dL}$ for women and $>18 \mathrm{~g} / \mathrm{dL}$ for men, and hematocrit $>62.1 \%)^{5}$, dyslipidemia (total cholesterol $>200 \mathrm{mg} / \mathrm{dL}$ and HDL-C $<70 \mathrm{mg} / \mathrm{dL}$ ) ${ }^{6}$, high blood pressure (systolic blood pressure $>130 \mathrm{mmHg}$ and diastolic pressure $>80 \mathrm{mmHg}^{7}$, established and controlled type 2 diabetes mellitus $\left(\mathrm{HbA}_{\mathrm{lc}}<7.0 \%\right)^{8}$, obesity $\left(\mathrm{BMI}>25 \mathrm{~kg} / \mathrm{m}^{2}\right)^{8}$, and smoking.

Supraventricular arrhythmias such as atrial fibrillation $(A F)$, atrial flutter (AFL), atrial tachycardia (AT), and ventricular and supraventricular extrasystoles were identified; no ventricular arrhythmias were identified. As ECG data of AF characteristics, an average heart rate of $78 \mathrm{bpm}$ and presence low voltage in the frontal plane were assumed to probably be attributed to overweight or lung disease and right bundle branch block in a 70-year-old patient, without left bundle branch block being found. 
Table 1. Patient general characteristics

\begin{tabular}{|c|c|}
\hline & Overall (162) \\
\hline Age & $68.7 \pm 12$ \\
\hline $\begin{array}{l}\text { Gender } \\
\text { Males } \\
\text { Females }\end{array}$ & $\begin{array}{l}77(47.5 \%) \\
85(52.5 \%)\end{array}$ \\
\hline $\begin{array}{l}\text { Pulmonary arterial hypertension } \\
\text { Mild pulmonary arterial hypertension } \\
\text { (PAP, } 35-50 \mathrm{mmHg} \text { ) } \\
\text { Moderate-to-severe pulmonary arterial } \\
\text { hypertension (PAP, } 51-70 \mathrm{mmHg} \text { ) }\end{array}$ & $\begin{array}{l}27(16.7 \%) \\
135(83.3 \%)\end{array}$ \\
\hline Erythrocytosis & $95(56.8 \%)$ \\
\hline Smoking & $41(25.3 \%)$ \\
\hline Obesity & $34(24 \%)$ \\
\hline High blood pressure & $63(38.9 \%)$ \\
\hline Dyslipidemia & $56(34.6 \%)$ \\
\hline Diabetes mellitus & $8(4.9 \%)$ \\
\hline $\begin{array}{l}\text { Right atrial dilatation } \\
\text { Mild dilatation (area }<18 \mathrm{~cm}^{2} \text { ) } \\
\left.\text { Moderate to severe dilatation (area, } 18-26 \mathrm{~cm}^{2}\right) \\
\text { Right ventricular dilatation }\end{array}$ & $\begin{array}{c}27(16.7 \%) \\
135(83.3 \%) \\
162(100 \%)\end{array}$ \\
\hline
\end{tabular}

For analysis, the SPSS statistical package, version 23.0, was used, and absolute frequencies, relative frequencies, and contingency tables were obtained; for related factors' analysis, Student's t-test was used for univariate analysis and the ANOVA test for multivariate analysis; in both analyses, related factors' relative risk (RR) was calculated.

\section{Results}

A total of 224 patients were analyzed; 62 did not meet the study inclusion criteria and 162 met the clinical, electrocardiographic, and echocardiographic inclusion criteria, with an average age of $68.7 \pm 12$ years $(52.5 \%$ females); patient general characteristics are described in table 1.

Most common arrhythmias were identified to be $\mathrm{AF}$, with 125 (77\%); AFL, with 17 (11\%); AT, with 17 (10\%); and ventricular and supraventricular extrasystoles, with $3(2 \%)$; no ventricular tachycardia episodes were identified (Fig. 1).

In the univariate analysis (Table 2), the main factors related to the development of arrhythmias were erythrocytosis, moderate pulmonary arterial hypertension, moderate and severe RA dilatation, obesity, and high
Table 2. Univariate analysis

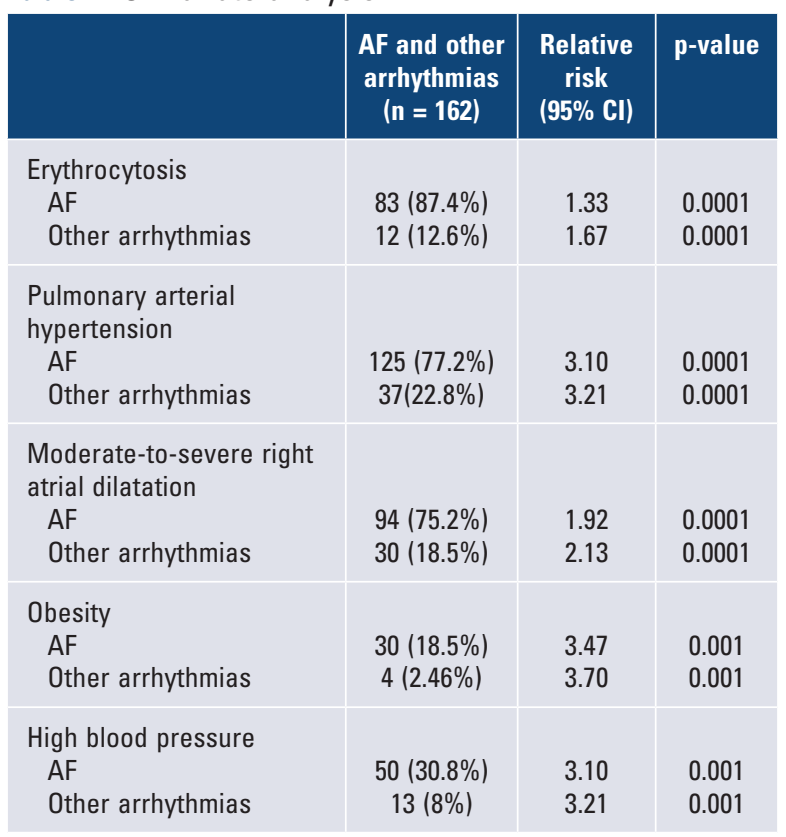

AF: Atrial fibrillation.

blood pressure. When the multivariate analysis was performed (Table 3), a higher statistical significance was observed for erythrocytosis and moderate-to-severe RA dilatation as supraventricular arrhythmias development promoting factors, in particular AF.

\section{Discussion}

The cities of La Paz and El Alto (Bolivia) have a numerous high-altitude native population, which makes for patients with arrhythmias in this population to be of particular interest; some of the pathophysiological aspects that are involved in their development differ from those in the rest of populations that live at lower altitudes ${ }^{1}$.

Natives residing at high altitudes actually have higher pulmonary pressure in comparison with those who live at sea level ${ }^{1}$; this, added to the high incidence of lung disease and tuberculosis present in this setting, contributes for the incidence of CCP to be very high ${ }^{3}$.

In addition, due to various factors, CCP patients have been observed to tend to develop cardiac arrhythmias, especially of the supraventricular type ${ }^{9}$, including RA dilatation ${ }^{10}$, which is secondary to the severe pulmonary hypertension associated with this disease, and both trigger an alteration in atrial remodeling ${ }^{11}$.

Very few studies in the world describe the relationship with these aspects; most correspond to descriptions of 
Table 3. Multivariate analysis (ANOVA) of risk factors for the development of arrhythmias

\begin{tabular}{|l|c|c|}
\hline Risk factors & $\begin{array}{c}\text { Relative } \\
\text { risk (RR) }\end{array}$ & p \\
\hline Erythrocytosis & 2.2 & 0.0001 \\
\hline Right atrial dilatation & 1.2 & 0.0001 \\
\hline Pulmonary arterial hypertension & 1.01 & 0.001 \\
\hline
\end{tabular}

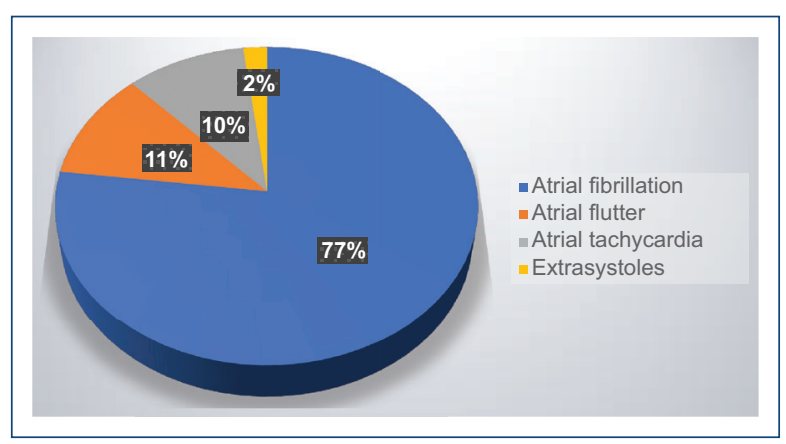

Figure 1. Arrhythmias frequency.

isolated reports on the incidence of cardiac arrhythmias at high altitude.

In the presence of chronic hypoxia-associated RA dilation, the most common cardiac arrhythmias that are to be expected include AFL, supraventricular extrasystoles, and AT; however, in this protocol, the main cardiac arrhythmia in patients with CCP was observed to be $\mathrm{AF}$ in a large percentage $(77 \%)$ and, much less frequently, AFL (11\%); this entails that, in addition to factors such as pulmonary hypertension and right cavities' dilatation secondary to chronic hypoxemia, factors that generate supraventricular arrhythmias, including erythrocytosis, may intervene.

In the multivariate analysis, the presence of erythrocytosis was found to be the most important risk factor for the development of AF (RR, 2.02; $p=0.0001)$ and, to a lesser extent, right atrial moderate dilatation (RR, 1.02).

One of the causes of pulmonary artery hypertension is chronic altitude sickness (defined as a loss of adaptation to high altitudes), which can be primary or an effect of lung disease, obesity, sleep apnea, and old age. As a consequence, a compensatory response is activated, and erythropoietin secretion and erythrocyte load are increased ${ }^{12}$; the presence of secondary pulmonary hypertension increases mortality so that these cases are related to high RV hypertrophy, distal pulmonary arteries excessive muscularization, and adventitial thickening ${ }^{13}$.

It has been postulated that chronic hypoxia at high altitudes, added to a chronic loss of acclimatization to altitude (chronic altitude sickness) and chronic inflammation, might favor the establishment of a pathophysiological substrate, known as triple hypoxia, and influence on high-altitude pathological erythrocytosis accelerated development ${ }^{13}$.

The development of secondary erythrocytosis in a patient with CCP living at high altitudes is, therefore, an adverse prognostic factor that predisposes to the development of AF, which, in turn, contributes to hemodynamic deterioration of these patients ${ }^{9,11}$.

In addition, the probability of developing cardiovascular episodes in the ensuing 10 years has been observed to be higher in subjects with erythrocytosis, in comparison with patients without it, and this probability is higher in the subgroup of individuals with moderate-to-severe pulmonary arterial hypertension ${ }^{14}$.

A hypothesis that may explain the pathophysiology of $\mathrm{AF}$ indicates that, initially, high-altitude hypoxia occurs and, in some cases, it can be added to a chronic loss of acclimatization to altitude, which causes chronic alveolar hypoventilation ${ }^{15}$, followed by an increased stimulation of erythropoietin production ${ }^{16}$, which increases the production of red blood cells.

Once pathological erythrocytosis is established, a chronic inflammatory state and vascular rheology alteration due to higher blood viscosity are produced, which, in turn, predisposes to high blood pressure ${ }^{17}$ and also leads to decreased tissue oxygenation, with endothelial dysfunction appearance.

Chronic heart disease, a constant inflammatory state, and endothelial dysfunction are substrates that are characteristically described as predisposing factors for AF genesis ${ }^{18,19}$, as also high blood pressure has ${ }^{20}$, but not erythrocytosis.

Inflammation partly causes atrial structural and electrical remodeling; in its presence, atrial conduction heterogeneity is accentuated by altering the expression of connexins, a factor that alters intercellular coupling ${ }^{21}$.

Once AF is chronically established, it worsens the clinical state of the patient with $\mathrm{CCP}^{9}$ and, in turn, it increases patient hemodynamic deterioration. For this reason, the development of erythrocytosis becomes an important risk factor in the genesis of AF and, therefore, for poor prognosis in patients with CCP. 


\section{Conclusions}

The most common arrhythmia in high-altitude inhabitants with CCP is AF. The risk factors for the development of cardiac arrhythmias, especially AF, in patients with CCP who live at high altitudes, are erythrocytosis and RA severe dilatation.

\section{Acknowledgments}

The authors express their appreciation to the National Institute of Thorax medical staff.

\section{Funding}

This research did not receive financial aid from agencies of the public, private, or commercial sectors.

\section{Conflicts of interest}

None.

\section{Ethical disclosures}

Protection of human and animal subjects. The authors declare that no experiments were performed on humans or animals for this research.

Confidentiality of data. The authors declare that they have followed the protocols of their work center on the publication of patient data.

Right to privacy and informed consent. The authors have obtained informed consent from the patients or subjects referred to in the article. This document is in the possession of the corresponding author.

\section{References}

1. Instituto Boliviano de Biología de Altura (IBBA), Comité Organizador de los VIII Juegos Deportivos Bolivarianos. Parámetros Biológicos Normales. 1ra ed. La Paz-Bolivia, 1977.

2. Budev MM, Arroliga AC, Wiedemann HP, Matthay RA. Cor pulmonale: an overview. Semin Respir Crit Care Med. 2003;24(3):233-43.
3. Díaz LA. Cor pulmonale crónico: aspectos clínicos epidemiológicos en adultos de altura. Rev Per Cardiol. 2009;35(1):44-52.

4. 2bago.bo [Internet]. La Paz: Cor pulmonale crónico: causas, enfermedades asociadas y características evolutivas en 2172 pacientes internados, Hospital Obrero N 1, La Paz, Bolivia; C2017 (consultado 18 febrero de 2017). Disponible en: https://www2.bago.com.bo/sbc/latido/Vol5_n6/html/ cor_pulmonale.htm

5. Amaru R, Torres G, Quispe T, Mamani J, Peñaloza R, Miguez H. Eritrocitosis patológica de la altura. 1ra ed. La Paz: Unidad de Biología Italo-Boliviano, 2016.

6. Catapano AL, Graham I, Backer G, Wiklund O, Chapman MJ, Drexhel H, et al. Guía ESC/EAS 2016 sobre el tratamiento de las dislipemias, Grupo de Trabajo de la Sociedad Europea de Cardiología (ESC) y la European Atherosclerosis Society (EAS) sobre el tratamiento de las dislipemias desarrollada con la colaboración especial de la European Association for Cardiovascular Prevention \& Rehabilitation (EACPR). Rev Esp Cardiol. 2017;70(2):115.e1-e64.

7. Reboussin DM, Allen NB, Griswold ME, Guallar E, Hong Y, Lackland DT et al. Systematic Review for the 2017 ACC/AHA/AAPA/ABC/ACPM/AGS/ APhA/ASH/ASPC/NMA/PCNA Guideline for the Prevention, Detection, Evaluation, and Management of High Blood Pressure in Adults: A Report of the American College of Cardiology/American Heart Association Task Force on Clinical Practice Guidelines. Hypertension 2018;71(6):e116-e135.

8. Piepoli MF, Hoes AW, Agewall S, Albus C, Brotons C, Catapano AL, et al. Guía ESC 2016 sobre prevención de la enfermedad cardiovascular en la práctica clínica, Sexto Grupo de Trabajo Conjunto de la Sociedad Europea de Cardiología y otras Sociedades sobre Prevención de Enfermedad Cardiovascular en la Práctica Clínica (constituido por representantes de 10 sociedades y expertos invitados) desarrollada con la contribución especial de la European Association for Cardiovascular Prevention \& Rehabilitation (EACPR). Rev Esp Cardiol. 2016;69(10):939.e1-e87.

9. Hernández SP, Lázaro SM, Alcalá JE, Macías CB. Cor pulmonale. Medicine 2017;12(35):2116-26.

10. Waligóra M, Tyrka A, Miszalski TJ, Urbanczyk ZM, Podolec P, Kopéc G et al. Right atrium enlargement predicts clinically significant supraventricular arrhythmia in patients with pulmonary arterial hypertension. Heart and Lung 2018;47(3):237-242.

11. Smith B, Genuardi MV, Koczo A, Zou RH, Thoma FW, Handen A, et al. Atrial arrhythmias are associated with increased mortality in pulmonary arterial hypertension. Pulm Circ. 2018;8(3):1-9.

12. Peñaloza $D$. Efectos de la exposición a grandes alturas en la circulación pulmonar. Rev Esp Cardiol. 2012;65(12):1075-78.

13. Peñaloza D, Arias SJ. The heart and pulmonary circulation at high altitude. Healthy highlanders and chronic mountain sickness. Circulation 2007;115(9):1132-46.

14. Prchal JT, Prchal JF. Williams hematology. $9^{\text {th }}$ ed. New York: McGraw Hill, 2015.

15. Acinelli RA, López LM. Enfermedades por exposición a la altura. Arch Bronconeumol. 2018;54(3):115-116.

16. Uscamayta QN. Eritrocitosis de altura patológica. Rev Cientif. 2007;5:50-6.

17. Marzal $D$, Rodríguez $L$. Etiología y prevención de la fibrilación auricular. Rev Esp Cardiol Supl. 2016;16(A):8-11.

18. Ramírez JD, Agudelo FJ, Correa R, Gonzales E. Fisiopatología de la fibrilación auricular. Rev Colomb Cardiol. 2016;23(S5):9-14.

19. Patel $P$, Dokainish H, Tsai P, Lakkis N. Update on the association of inflammation and atrial fibrillation. $\mathrm{J}$ Cardiovasc Electrophysiol. 2010;21(9):1064-70.

20. Aldashev AA, Sarybaev AS, Sydykov AS, Kalmyrzaev BB, Kim EV, Mamanova LB, et al. Characterization of high-altitude pulmonary hypertension in the kyrgyz: association with angiotensin-converting enzyme genotype. Am J Respir Crit Care Med. 2002;166(10):1396-1402.

21. Corante C, Ramírez CA, Figueroa R, Macarlupu JL, Galindo GV, Bilo G, et al. Excessive erythrocytosis and cardiovascular risk in andean highlanders. High Alt Med Biol. 2018;19(3):221-231. 